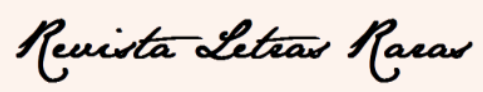

ISSN: 2317-2347 - v. 7, n. 2 (2018)

\title{
Do conto à quadrinização: \\ impactos narrativos da transposição multimodal de La belle et la bête ${ }^{1 /}$ From short story to comics: narrative impacts of the multimodal transposition of La belle et la bête
}

\author{
Danielle Alves da Rocha* \\ Ana Luiza Ramazzina Ghirardi*
}

\begin{abstract}
RESUMO
O presente artigo visa examinar a transposição de uma narrativa monomodal para uma multimodal, servindo-se para isso do conto maravilhoso La Belle et la Bête de Madame de Leprince de Beaumont (1756) e de sua respectiva adaptação para a HQ (L’Hermenier, 2014). Para analisar o processo de transposição da linguagem literária para a quadrinização e verificar seus impactos, além dos conceitos sobre gênero fantástico, maravilhoso e ficção científica e tradução intersemiótica, serão utilizados como referência teórica os trabalhos de Barros (2009), Cagnin (2015), Dionisio (2011), Dondis (2003), Frase (2007), Hemais (2014), Plaza (2013), Sodré (1973), Todorov (2008)
\end{abstract}

PALAVRAS-CHAVE: La Belle et la Bête. Transposição Multimodal. HQ. Gênero Fantástico. Gênero Maravilhoso.

\section{ABSTRACT}

This article examines the transposition of a narrative from monomodal to multimodal form by analyzing the gothic fairy tale La Belle et la Bête by Madame de Leprince de Beaumont (1756) and its adaptation into comics (L'Hermenier, 2014). The concepts of gothic genre, fairy tales, sci-fi and intersemiotic translation are used to analyze the process of transposition from literary language to that of comics and examine its impact on the narrative. The theoretical framework is provided by works by Barros (2009), Cagnin (2015), Dionisio (2011), Dondis (2003), Frase (2007), Hemais (2014), Plaza (2013), Sodré (1973), Todorov (2008)

KEYWORDS: La Belle et la Bête. Multimodal transposition. Comics. Gothic genre. Fairy tales.

\section{Introdução}

Ao viver em uma sociedade cada vez mais imagética, na qual a combinação da linguagem verbal à visual proporciona novas construções de sentidos, é necessário observar, analisar e apresentar formas e suportes de transmissões comunicacionais

\footnotetext{
${ }^{1}$ Resultado final da pesquisa, submetida à FAPESP, Do conto à quadrinização: Impactos narrativos da transposição multimodal de La Belle et la Bête.

* Graduanda em Letras (Português/ Francês) pela EFLCH/UNIFESP - Campus Guarulhos. Endereço eletrônico: danirocha.letras@gmail.com.

** Professora na área de língua e literatura francesas do departamento de letras da Escola de Filosofia, Letras e Ciências Humanas da Universidade Federal de São Paulo / UNIFESP. Pós-doutora com pesquisa em estudos da tradução (em sua relação com o ensino) no Instituto de Estudos da Linguagem (IEL), UNICAMP. Endereço eletrônico: alramazzina@uol.com.br.
} 


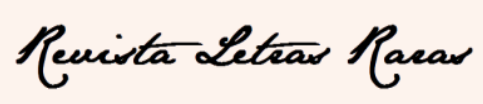

ISSN: 2317-2347 - v. 7, n. 2 (2018)

(DIONISIO, 2011, P. 146-149). Os estudos relacionados à multimodalidade estão em constante crescimento, principalmente aqueles relacionados à área de letramento e ensino. São muitos os pesquisadores interessados neste campo de estudo, como Dionisio (2011), Hemais (2010), Kock e Elias (2013); soma-se a isso uma crescente vertente que estuda a construção do sentido por meio da multimodalidade, como Plaza (2013), Lebrun, Lacelle e Boutin (2012), dentre outros.

Esses estudos estão estreitamente ligados a uma nova dinâmica pela qual a sociedade contemporânea tem passado nas últimas décadas. Assiste-se a uma revisão e ampliação de alguns conceitos no campo dos estudos das relações humanas e do processamento textual em decorrência das novas tecnologias e de suas influências diretas nas interações sociais. Para Dionisio (2011), o primeiro conceito a ser revisto é o de letramentro, termo relacionado à capacidade de atribuir sentido a mensagens provindas de diversas fontes de linguagens, fazendo com que o sujeito se torne capaz de compreender e reproduzir mensagens incorporando a elas múltiplas modais (DIONISIO, 2011, p. 137). Para a autora, a forma de comunicação humana (2011, p. 139-140) é multimodal, pois são ações sociais que possuem um traço constituinte do discurso oral e escrito: quando a linguagem é acionada, ações individuais e sociais são realizadas, representando manifestações socioculturais que, por sua vez, materializam-se em gêneros textuais. Assim, as formas visuais dessas ações resultam em infinitas possibilidades de combinações entre a palavra (oral e escrita) e o visual (imagem), configurando-se assim em multimodalidade.

Já Hemais (2014, p. 1) denomina a multimodalidade como a co-presença de vários modos de linguagem que interagem na construção social; esses modos semióticos funcionam em conjuntos que, por sua vez, contribuem conforme suas características para a criação de significações proporcionando assim novos gêneros ${ }^{2}$ através da interação de multimodais. Assim, segundo a concepção de Unsworth (2001, p. 8 apud HEMAIS, 2010, p.1), é necessário aprender e entender que há três linguagens a serem adquiridas: a verbal, a visual e a digital. Segundo o autor, elas são independentes,

\footnotetext{
${ }^{2}$ Bakhtin (2008, p. 262-265) denomina gêneros discursivos o resultado da combinação do conteúdo temático, do estilo de linguagem e a construção composicional do enunciado, sendo que é indissolúvel, pois faz uma ligação em torno do enunciado e determina um campo de comunicação.
} 


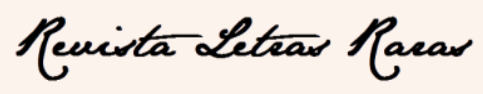

ISSN: 2317-2347 - v. 7, n. 2 (2018)

interativas e essenciais na construção de significações das mensagens e serão requisitadas no momento de uma interpretação verbal, escrita ou visual para que a comunicação seja completa.

Esse artigo se interessa especialmente pelo gênero multimodal HQ. O estudo da forma de construção do sentido por meio de modais tem relevância ao verificar a aplicação das concepções teóricas da multimodalidade na concepção de imagens sequenciais; segundo Dondis (2003), a maior parte deste material registra, preserva, reproduz e identifica pessoas, lugares, objetos e classes de dados visuais. Considerando a ideia de releitura de um texto monomodal e suas implicações em uma versão $\mathrm{HQ}$, o presente artigo examina a transposição de uma narrativa verbal (monomodal ${ }^{3}$ ) para uma narrativa com uma pluralidade de recursos semióticos (multimodal) a partir de excertos do conto maravilhoso La Belle et la Bête de Madame de Beaumont (1756) e de sua respectiva adaptação para a HQ homônima, - de L'Hermenier (2014, 2015).

A escolha de um conto e de uma HQ se dá com o objetivo de analisar e descrever as estratégias de transposição da linguagem literária monomodal (verbal) de um conto maravilhoso para a linguagem multimodal de uma HQ (diferentes recursos semióticos), e verificar os impactos causados pelo processo de transposição de um sistema de signos para outro. Serão observados ainda quais elementos da estrutura do gênero maravilhoso mantiveram-se ou foram alterados, bem como a evidência de influência de outros gêneros.

\section{La Belle et la Bête: uma narrativa recriada}

Neste artigo, serão cotejadas algumas passagens do romance La Belle et la Bête (1740), do conto homônimo (1756) e da HQ (graphic novel ${ }^{4}$ ) também homônima de

\footnotetext{
${ }^{3} \mathrm{Na}$ área de estudo da multimodalidade define-se que não há textos que sejam monomodais como afirma Nascimento (2012) “(....) pesquisas partem da premissa básica de que não existem textos monomodais ou monosemióticos, já que, mesmo em textos predominantemente verbais, utilizamos recursos visuais, tais como tipografia e formatação(...)". Para este artigo, com o intuito de verificar a transposição de um conto e romance para um gênero multimodal (HQ), considera-se o texto monomodal aquele que predominantemente é constituído pelo discurso e enunciado verbal sem apoio imagético para a criação do seu sentido.

${ }^{4}$ Essa HQ é considera graphic novel pelo mercado literário. Segundo Rodrigues (2013), a graphic novel seria uma nova forma contemporânea de composição da $\mathrm{HQ}$, com a proposta de reinventar a forma de
} 


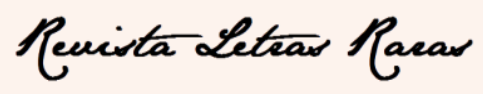

ISSN: 2317-2347 - v. 7, n. 2 (2018)

L'Hermenier, (2014, 2015, tombos 1 e 2). Segundo Rodrigues (2013), a grafhic novel possui uma "postura antirromancesca", pertencente ao movimento contemporâneo, que consiste na ideia de que o romance literário reduz, fragmenta reinventa a sua forma, diluindo o seu conceito primordial, enquanto o romance gráfico aumenta esta extensão.

O autor aponta (2013) que uma das principais características de uma graphic novel é a escolha de "temas mais adultos" que permeiam as narrativas; em La Belle et la Belle (2014) passagens como o assassinato de uma mãe frente ao filho pequeno, a vingança dele pela morte materna, cenas de nudez e referências eróticas comprovam a escolha dessa temática. Já García (2012) aponta o afastamento da estrutura "comic", focalizada no público infantil, para uma perspectiva mais adulta, que prevalece a memória, a história, a ficção, e temas universais, aglutinados a um conceito estético que permite uma unidade. Na HQ La Belle et la Bête (2014, 2015), este conceito estético está entrelaçado à narrativa, pois há uma reestruturação da exposição dos acontecimentos devido às escolhas estéticas (isto será abordado mais adiante).

La Belle et la Bête é uma obra que sofreu ao longo dos anos diversas transposições, passando, desde sua publicação original até as adaptações mais recentes, por aumentos e diminuições de informações estéticas. O romance escrito por Suzanne Barbot de Gallonde Villeuneuve, La Belle et la Bête (1740), na coleção La jeune amériqueiaine et les contes marins, representa a primeira versão publicada dessa narrativa. Escrita em uma linguagem simples, esta narrativa tinha como objetivo educar e distrair jovens inglesas que aprendiam francês. A segunda versão, um conto escrito em 1756 por Jeanne-Marie Leprince de Beaumont, tinha como público alvo jovens prestes a se casar (esta é considerada a primeira transposição do romance). Durrenmath (2011, p. 13-14) afirma que Leprince de Beaumont suprimiu três longas passagens do conto original. Houve omissões de descrições de encantamentos do palácio, de um sonho de Belle, de eventos sobre o passado de Bête; ocorreram supressões de elementos eróticos e houve a simplificação da história e do estilo literário, contudo as linhas narrativas principais foram conservadas.

romance agregando o literário e unindo outras formas de linguagens. Com uma abordagem mais ampla de temas e público alvo adulto, agregando a estrutura clássica à análise psicológica e um processo de interiorização. 


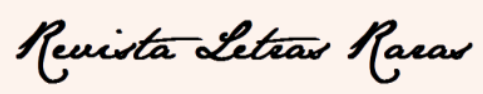

ISSN: 2317-2347 - v. 7, n. 2 (2018)

Uma das mais recentes adaptações do conto consiste na HQ La Belle et la Bête (2014, 2015) de L'Hermenier, objeto desse artigo, que, além de adaptar o conto e retomar trechos do romance original, transmutou elementos e acrescentou novas linhas narrativas. A HQ $(2014,2015)$ retoma o nome de personagens e muitos elementos do romance de 1740 e do conto de 1756, além de apresentar alguns personagens e ações narrativas semelhantes às duas obras. Contudo a versão se apropria desses elementos para a construção de uma nova história recriando por meio de hipertextos e interferências as duas obras anteriores.

A HQ La Belle et la Bête $(2014,2015)$ narra a história de Belle, uma jovem inteligente que gosta de ler e é dedicada à família. Filha de um comerciante, dono de barcos, tem duas irmãs mais velhas que a exploram (ela é encarregada de todos os serviços domésticos da casa). A família vive em um pequeno vilarejo próxima a um rio em que, anos antes, sofreu um ataque noturno por um barco voador que provocou muitas mortes na população. A partir de uma armação do prefeito do vilarejo, o pai de Belle perde sua fortuna e seus barcos. O prefeito propõe restituir a fortuna ao mercador desde que ele lhe dê a mão de sua filha Belle em casamento, contudo o mercador recusa esta oferta.

Paralelamente, à história de Belle, a HQ narra a história de Gwendal e sua esposa Diane, príncipes aprisionados por um mago em uma estranha maldição. O Mago é apaixonado por Diane, a princesa que adora rosas e todas as tardes vai ao jardim para admirá-las. Um dia, encontra Gwendal, um belo príncipe e se apaixona por ela. Os dois se casam e o Mago, enciumado, no dia do casamento transforma Diane em pedra e Bête em fera. Transformado em Bête, Gwendal se torna um pirata obrigado a buscar por séculos almas negras para alimentar o Mago, sempre na esperança de libertar sua esposa Diane.

As vidas de Belle e Bête vão se cruzar no dia em que o prefeito tenta conseguir a mão de Belle. O barco voador de Bête e sua tripulação chegam à noite para saquear o vilarejo pela segunda vez. Belle não se recorda do primeiro ataque porque na época era muito pequena. Dessa vez, para proteger sua família, ela se oferece como prisioneira aos tripulantes que percebem nela a alma pura que buscam há muito tempo e a levam até 


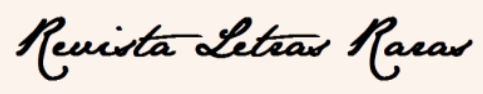

ISSN: 2317-2347 - v. 7, n. 2 (2018)

seu capitão. Ao ver Belle, nasce uma grande esperança em Bête que vê na moça a única alma pura capaz de libertar sua amada, Diane.

O filho do prefeito, Liam, ao ver que Belle é presa, entra escondido no barco para salvá-la. Os dois são amigos de infância e ele nutre uma paixão platônica por ela: ele é capaz de tudo para protegê-la. No ataque ocorrido no vilarejo anos antes, Liam presenciou o assassinato de sua mãe por uma grande fera. No início da história, Liam não sabe ao certo quem a matou mas, ao longo da narrativa, é revelado o assassino, Bête, o comandante daquele barco voador. Liam propõe a Belle tentar uma fuga, mas ela recusa, pois pretende salvar Diane. Ao ver que sua amada pretende ajudar o assassino de sua mãe, Liam se une ao Mago e acaba transformado em uma fera como Bête.

Belle consegue libertar Diane, mas agora tem que enfrentar seu amigo de infância. Após uma luta entre Bête e Liam, Belle revela a verdade a Liam sobre a morte de sua mãe: foi o pai de Liam que a matou. Para convencê-lo de sua sinceridade, ela finalmente se declara a ele e o beija conseguindo assim iniciar um retrocesso em sua transformação que logo é impedido pelo Mago. Com o intuito de tirar a humanidade de Bête, o Mago, no mesmo instante, ataca Belle mas Liam intervém e consegue matá-lo selando assim sua condição de fera para sempre. Bête volta a ser humano e, ao mesmo tempo, seu castelo começa a desmoronar; para salvar Diane, Liam se sacrifica e fica segurando a porta de entrada até que ela possa sair.

Belle, Bête e Diane escapam, a magia acaba e o barco, que não voa mais, chega por água no porto do vilarejo de Belle. Ela descobre que após a perda da fortuna de sua família, suas irmãs se tornaram serviçais do prefeito. Belle denuncia o prefeito que é preso, restitui a fortuna ao seu pai, e segue uma nova vida. No prólogo, Liam reaparece vivo visitando uma rosa para lembrar-se de Belle.

Do romance de 1740 e do conto de 1756, a HQ resgata como fio condutor a história da jovem que, para salvar a vida de seu pai, se oferece como prisioneira a uma fera e, por ser um personagem com muitos atributos morais, consegue converter a fera novamente em um príncipe, após superar várias batalhas. Esta releitura da história de Belle retextualiza o ambiente, as personagens e a forma de contar essa história criando 


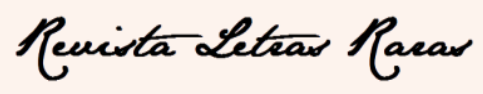

ISSN: 2317-2347 - v. 7, n. 2 (2018)

uma nova obra através de um tipo de transposição, a transmodalização (Genette, 1982) ${ }^{5}$, entre o romance o conto, e a HQ.

É importante ressaltar, que essa é uma das inúmeras versões de La Belle et la Bête que foi várias vezes recontada durante décadas. Além de recriar uma narrativa a partir de personagens imortalizados, a HQ La Belle et la Bête $(2014,2015)$ traz como originalidade a inserção de elementos mágicos que caracterizam aquilo que Todorov (2008) denomina gênero maravilhoso. ${ }^{6}$

Segundo Plaza (2013, p. 30), em uma tradução intersemiótica, os signos que foram utilizados em uma adaptação proporcionam novas formas, sentidos e estruturas que tendem a se desvincular do original, pois a eleição de signos induz a uma nova forma de linguagem, e um direcionamento de caminhos divergentes de encaminhamentos inerentes às suas estruturas. Este artigo analisa excertos das HQ $(2014,2015)$ para discutir a criação de novos sentidos através do rearranjo semiótico dos signos.

Sanders (2006, apud VIEIRA, 2010, p.2) aponta que transportar um texto de um gênero específico para outro modo genérico é uma prática transposicional, logo, uma adaptação implica reinterpretar textos fundadores em novos contextos, podendo ou não ocorrer alterações culturais, de ordem temporal ou narrativa, bem como simplificações ou adições e transformações estruturais no novo segmento textual. Para Campos (1981), transposição é re-correr ao percurso configurador da função poética, reconhecendo-o no texto de partida e reinscrevendo-o em um dispositivo de engendramento textual na língua do tradutor para passar da obra transcrita para uma nova obra original.

Esse fenômeno pode ser constatado no início do conto e do romance La Belle et la Bête. No romance de Villeneuve (2010), a autora introduz já nas primeiras linhas o lugar e os personagens:

Dans un pays fort éloigné de celui-ci, l'on voit une grande ville, où le commerce florissant entretient l'abondance. Elle a compté parmi ses citoyens un marchand heureux dans ses entreprises, et sur qui la fortune, au gré de des désirs, avait toujours répandu ses plus belles

\footnotetext{
5 "Notre dernier type de transposition (en principe) purement formelle sera la transmodalisation, soit toute espèce de modification apportée au mode de représentation caractéristique de l'hipotexte" (GENETTE,1982, p. 395).

${ }^{6}$ Gênero que consiste na criação de novas regras, aceitas dentro da narrativa como formas naturais, que perdem a relação direta com a realidade (TODOROV, 2008).
} 


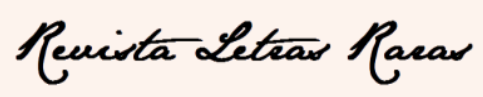

ISSN: 2317-2347 - v. 7, n. 2 (2018)

faveurs. Mais s'il avait des richesses immenses, il avait aussi beaucoup d'enfants. Sa famille était composée de six garçons, et de six filles. (...) (VILLENEUVE, 2010, p. 19) ${ }^{7}$

Leprince de Beaumont (2011), ao adaptar o romance para um conto, inicia sua narrativa da seguinte forma:

Il y avait une fois un marchand qui était extrêmement riche. Il avait six enfants, trois garçons et trois filles, et comme ce marchand était un homme d'esprit, il n'épargna rien pour l'éducation de ses enfants et leur donna toutes sortes de maître. (LEPRINCE DE BEAUMONT, 2011, p. 9). ${ }^{8}$

Em ambos os trechos há a apresentação da família, composta pelo pai mercador e seus filhos. Na segunda versão, essa característica familiar foi transposta, mas reduzindo o número de filhos a duas irmãs (no primeiro texto, são seis rapazes e seis moças). Nesse sentido, a transposição HQ $(2014,2015)$ recupera alguns elementos do conto (LEPRINCE DE BEAUMONT, 1756) preferindo assim abordar a relação entre as duas irmãs más e egoístas a acrescentar todos os personagens do romance (1740) ${ }^{9}$.

Neste novo gênero, a HQ, há uma hipertextualização das duas histórias anteriores com a retomada direta e indireta de seus elementos. Vale ressaltar que um dos principais impactos narrativos que a história sofreu nessa nova adaptação, de uma narrativa monomodal, do romance (1740) e do conto (1756), para a HQ (2014, 2015), foi a abstração espaço-temporal.

Quando Leprince de Beaumont (2011) transpôs pela primeira vez o romance de Villeneuve (1740), houve o processo que Genette (1982, p. 315) denomina de transestilização ${ }^{10}$. Essa transestilização continua na transposição multimodal da HQ (2014, 2015), além de manter uma relação intertextual com as duas obras anteriores.

\footnotetext{
${ }^{7}$ Era uma vez um comerciante muito rico, que tinha seis filhos: três meninos e três meninas. Como esse comerciante era um homem inteligente, não poupou recursos na educação de seus rebentos, dando-lhes todo tipo de professores. (LEPRINCE DE BEAUMONT, 2016, P. 31)

${ }^{8}$ Havia certa vez um comerciante que era muito rico, muito rico. Tinha seis filhos, três meninos e três meninas. E, como era um homem inteligente, não poupou esforços para a educação de seus filhos, que foram ensinados por todos os tipos de mestres. (LEPRINCE DE BEAUMONT, 2014 p. 17).

${ }^{9}$ Como será possível verificar mais à frente, ao se tratar de intertextualidade, esta escolha impactará na narratividade trazendo um elemento intertextual de outra história bem conhecida: Cinderela.

${ }^{10}$ Comme l'indique clairement son nom, la transtylisation est une récriture stylistique, une transposition dont la seule fonction est un changement de style (GENETTE, 1982, p. 315).
} 


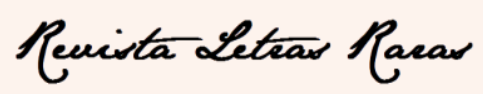

ISSN: 2317-2347 - v. 7, n. 2 (2018)

\section{Transestilização do Gênero Maravilhoso para a Ficção Científica na abertura da HQ}

A HQ La Belle et la Bête (2014) tem em sua abertura (Fig. 1) o barco voador de Bête que introduz o vilarejo em que Belle mora e apresenta Liam no dia em que sua mãe é assassinada (como será possível verificar ao longo da história). A sua construção se dá por meio de um quadro panorâmico que, segundo Gagnin (2015, p. 109), tem a função de localizar geograficamente a cena onde se passará a ação dos quadrinhos, juntamente com as indicações textuais dos apêndices, como comprova o início da HQ:

Tous les contes commencent par «il était une fois »... mais celui-ci n'est pas comme les autres... Il prend place aux temps des mythes et des légendes [...] Aux confins d'une contrée reculée, un enfant s'apprête à s'endormir sans se douter qu'une terrible menace se dirige vers son village... (L'HERMENIER, 2014, p. 3). ${ }^{11}$

Os fragmentos acima se referem a uma indeterminação temporal (ainda que tenha o uso do tempo verbal presente do indicativo), pois o vilarejo é ancorado e apresentado pelas imagens, sem especificações precisas. O espaço geográfico é indefinido, não há a localização espacial do vilarejo. Há aqui uma relação direta com o início do texto de Villeneuve (2010), visto que é o narrador em seu romance quem indica a localização, o espaço-temporal no parágrafo inicial. O que leva a supor que o autor da HQ (2014, 2015) apropriou-se das duas narrativas para compor sua nova história, pois a primeira página da HQ (2014) remete a essa passagem do romance de 1740 : "Dans un pays fort éloigné de celui-ci, l'on voit une grande ville, où le commerce florissant entretient l'abondance.. (...)" (VILLENEUVE, 2010, p. 19). ${ }^{12}$

\footnotetext{
${ }^{11}$ Todos contos começam por "era uma vez..." mas esse não é como os outros... Aconteceu nos tempos dos mitos e das legendas [...] Nos confins de uma terra distante, uma criança se prepara para dormir sem perceber que uma ameaça terrível se dirige para sua cidade... (L'HERMENIER, 2014, p. 3, tradução nossa).

${ }^{12}$ Em um país bem distante daqui, desponta uma grande cidade em que o comércio próspero conserva a abundância... (VILLENEUVE, 2015, p. 19, tradução nossa).
} 


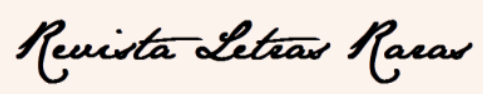

ISSN: 2317-2347 - v. 7, n. 2 (2018)

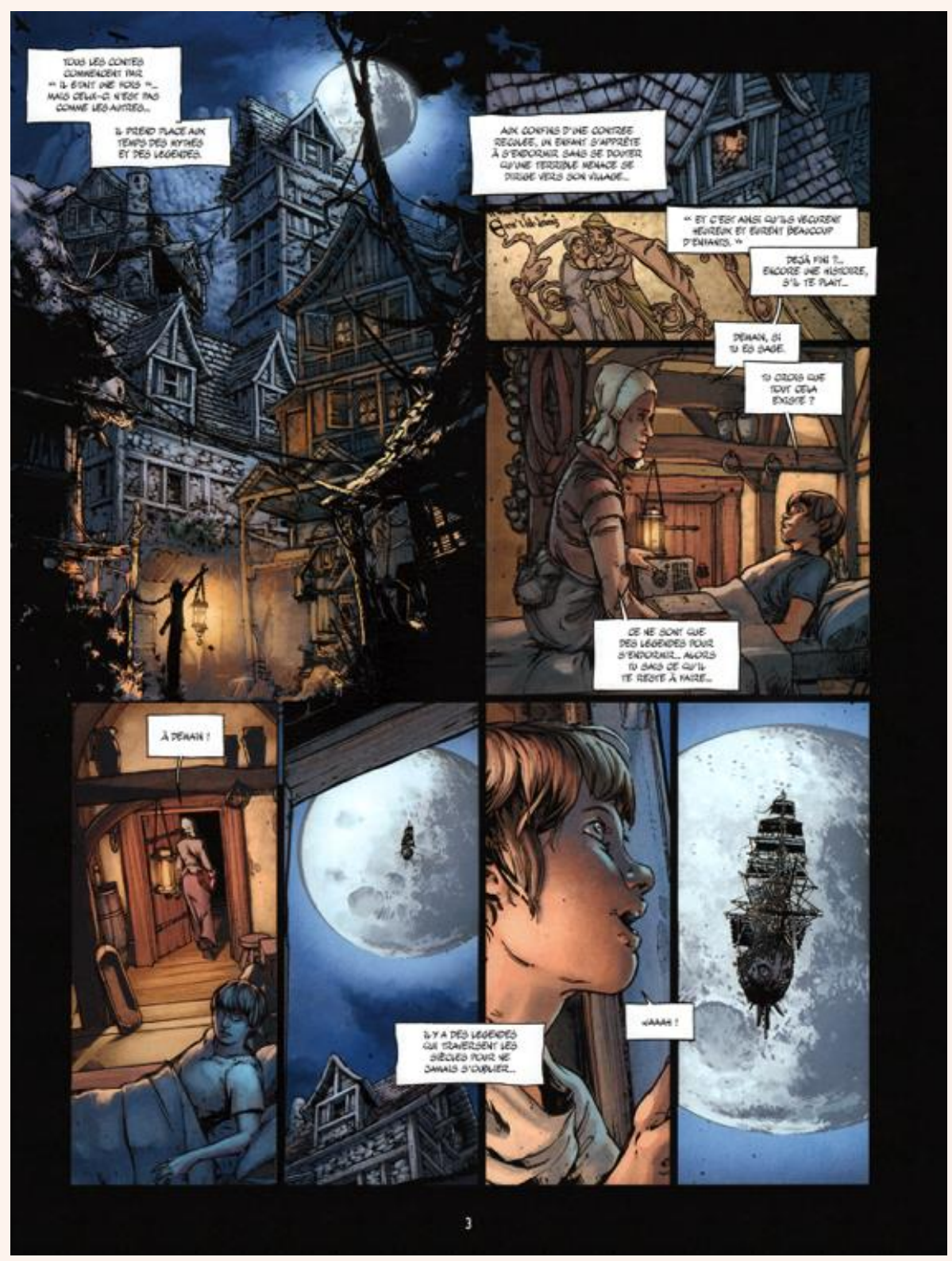

Fig. 1: L’Hermenier, 2014, p. 3

A cena localizada no primeiro quadrinho (Fig 1) da HQ (2014), retoma a introdução espaço-temporal feita em Villeneuve (2010). Aquilo que é descrito textualmente no romance aqui é contado por meio de imagens e outros recursos próprios à linguagem HQ. O desenho de um vilarejo, com muitas casas amontoadas domina a imagem. A lua e as cores escuras indicam o período noturno; a cor azul escura e tons de preto indicam a penumbra. As casas são feitas de madeira e pedra, sem uma 


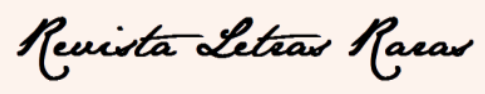

ISSN: 2317-2347 - v. 7, n. 2 (2018)

padronização harmoniosa, indicando que ali vivem pessoas em condições de vida estáveis, mas sem luxo.

Os três quadrinhos à direita introduzem a ação: uma aproximação da janela do último andar da casa mais alta mostrada no plano panorâmico tem a função de abranger parte do rosto de uma figura humana ou objetos para constituir um contato com momentos intensos da narrativa (GAGNIN, 2015). É possível ver a silhueta de uma mulher e uma criança, o interior do quarto, de uma perspectiva de visão do alto para baixo; isso gera um índice da aproximação do barco voador e da ameaça enunciada pelo narrador no apêndice, pois sugere que os tripulantes do barco estão observando aquela cena e se preparam para o ataque. ${ }^{13}$

Há a presença de luz em algumas janelas, elemento indicado pelas nuanças de amarelo, contrapondo os tons escuros, do azul e do preto, que representam a noite. Uma focalização na janela do prédio mais alto do vilarejo indica a luz e a presença de personagens (Fig.1). Observa-se que há a silhueta de duas pessoas, que no primeiro momento não é possível identificar. É possível notar uma pessoa que segura um livro e um jovem que a observa. No balão do quadrinho há a indicação de que aquele vilarejo está longe de qualquer outro ponto, é tarde da noite, as pessoas estão dormindo e um grande e terrível evento ocorrerá novamente.

O segundo e o terceiro quadros estão ligados por balões. O balão que representa a fala da personagem feminina tem formato retangular, com bordas levemente assimétricas, a sobreposição de imagens e balões criam o sentido de diálogo, de uma narração da história contada pela mãe ao seu filho. Os balões são encadeados em uma ordem temporal da emissão das falas dos personagens ${ }^{14}$ permitindo assim uma leitura coerente das ações (GAGNIN, 2015).

Segundo McCloud (2008, 142-143), as escolhas do formato e do estilo dos balões ocorrerá dependendo da necessidade narrativa, e este formato adequa-se à ideia que o escritor deseja transparecer. Pode-se dizer que nesses quadrinhos introdutórios, o

\footnotetext{
${ }^{13}$ Essa cena só terá continuação no tombo 2, nas páginas 4 e 5, quando o barco voador chega ao vilarejo, e seus tripulantes iniciam o ataque, matando e aprisionando as pessoas.

${ }^{14}$ «Et c'est ainsi qu'ils vécurent heureux et eurent beaucoup d'enfants » [...] Déjà fini ?... Encore une histoire, s'il te plaît... [...] Demain, si tu es sage. [...] Tu crois que tout cela existe ? (L'HERMENIER, 2014, p. 3).
} 


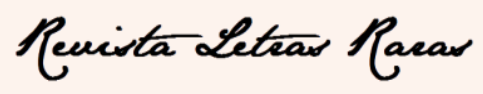

ISSN: 2317-2347 - v. 7, n. 2 (2018)

autor da HQ La Belle et la Bête (2014) sugere uma correlação e uma contraposição da imagem do livro de contos de fada à enunciação da personagem sobre a negação da existência de elementos fantásticos e maravilhosos.

O segundo quadrinho é o close de uma página do livro que a mãe de Liam lê para ele. Como dito, os balões ligam este quadro com o que está localizado abaixo, a cena em que aparecem os dois personagens, Liam, ainda criança, sentado na cama com sua mãe, criando assim uma linha condutora para que o leitor compreenda a narrativa. As duas figuras representadas por um quadro em close médio (GAGNIN, 2015, p. 107), empregado em cenas de diálogos, permite a percepção das expressões faciais com mais detalhes.

McCloud (2008, p. 30-31) diz que a escolha das palavras representa um poderoso aliado para a comunicação da mensagem, traz consigo um nível de especificidade, pois trabalha sem emenda com as imagens para criar o sentido. No caso dessa HQ La Belle et la Bête (2014, 2015), há aqui o que McCloud (2008, p. 128-129) denomina equilíbrio dinâmico, onde as palavras e as imagens juntas impelem a história a prosseguir, é a função de ligação do significado explanada por Gagnin (2015, p.138139). O diálogo entre mãe e filho tem como função enfatizar a enunciação do narrador onisciente (será retomado mais a frente neste artigo). Percebe-se ainda a interação entre a palavra e a imagem na narração (GAGNIN, 2015), cabendo à imagem a tarefa principal de contar a história, visto que é polissêmica, e pode ter múltiplos sentidos se ancorando na palavra que conduzirá a uma fixação dos significados. Imagem e palavra, na ótica de Gagnin (2015, p. 138-139), são os motores da história, constroem a narração, passo a passo, durante a leitura de um quadrinho para outro.

A construção imagética do vilarejo acrescida da interferência do narrador onisciente (Fig. 1) reconstrói a ideia de Villeneuve (2010), agora com a interação de elementos multimodais: imagens, cores, texto, movimentos etc. Aquilo que era descrito em um parágrafo, abrange, no tombo 1 da HQ (2014), metade de uma página causando um deslocamento de relevância. Enquanto que no romance esse trecho introduz a história e não é retomado de forma efetiva e nem tampouco é citado no conto de 1756 , na HQ (2014) a imagem do vilarejo adquire importância. Trata-se de um local distante e sem importância, que provavelmente não teve nenhum acontecimento marcante, mas 


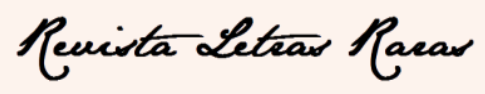

ISSN: 2317-2347 - v. 7, n. 2 (2018)

que será o local de um grande e trágico evento; a imagem adquire relevância na narrativa e se repete, depois de anos, quando a embarcação de Bête retorna ao vilarejo em busca de almas perversas para alimentar o Mago.

Este quadro panorâmico das casas representa o plano de fundo sobreposto pelos outros quadrinhos, serve de ligação e continuidade temporal, em que as ações são desencadeadas em sequência. As calhas entre os quadros são pretas, comparando-as com os outros momentos que aparecem na história, indicam as ações narrativas que culminarão no desenvolvimento do enlace narrativo. Gagnin (2015, p. 71) ressalta que as cores ao fundo nos quadrinhos podem desempenhar a função de índice. Segundo Fraser (2007, p. 49), a cor preta indica opressão, frieza, angústia, ameaça e perigo, e no tombo 1 da HQ La Belle et la Bête (2014) é claramente a representação da ameaça iminente.

Analisando mais atentamente a cartela de cores desta sequência de quadrinhos, percebe-se o predomínio do azul escuro e suas nuances para a representação da noite e tons de amarelo, além dos reflexos da lamparina acessa. Para Fraser (2007, p. 49) representa otimismo, confiança, força emocional, simpatia, autoestima, extroversão, o que pode ser atribuído à relação entre mãe e filho. $\mathrm{O}$ contraponto deste amarelo com as calhas negras, mais a frase do narrador “(...) un enfant s'apprête à s'endormir sans se

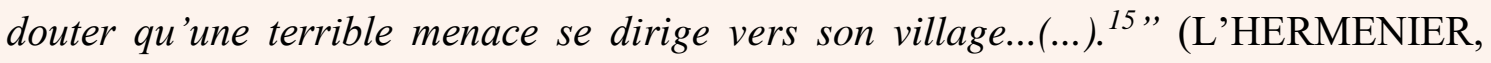
2014 , p. 3) conduz ao fim trágico da cena que ocorrerá na próxima página - o pavor estampado no rosto de Liam diante da morte de sua mãe (a palavra aqui não assume a narrativa pois a força imagética é soberana).

A conclusão narrativa desta primeira página se dá com o diálogo entre mãe e filho; ele pergunta se as histórias que lhe contam são verdadeiras, na esperança de ouvir uma afirmativa, mas a mãe lembra ao filho que representam apenas lendas para adormecer. No momento em que sua mãe se despede e se dirige à porta do quarto, Liam vê um barco voador se aproximar. A sequência de quadrinhos apresenta uma intercalação de ações concomitantes, que se dividem em três quadrinhos: o menino percebe a aproximação do barco e fica fascinado com aquela presença. Este sentimento

\footnotetext{
15 Uma criança se prepara para dormir sem suspeitar que uma terrível ameaça se aproxima da cidade. (tradução nossa)
} 


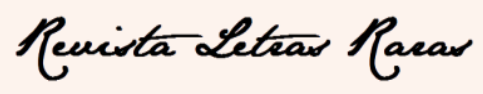

ISSN: 2317-2347 - v. 7, n. 2 (2018)

é reforçado pela introdução de um balão com a fala do narrador onisciente "há lendas que atravessam os séculos para nunca se esquecer..." (L'HERMENIER, 2014, p. 3, tradução nossa)

O último quadrinho que fecha a primeira sequência narrativa da página mostra o barco por uma perspectiva externa ao quarto e sem o foco visual de Liam, é um plano contre-plongé (GAGNIN, 2015, p. 110). A cena remete à grandiosidade do evento e à fragilidade que aquele vilarejo se encontra, pois todos dormem, e perceberão tarde demais a chegada do inimigo.

Groensteen (2011, p. 11) diz que por meio de cada imagem, tem-se a construção de forma linear de uma mensagem nas páginas. McCloud (1999 apud GROENSTEEN, 2011, p. 40) indica que a HQ é uma arte de intervalos e de espaços em que o leitor é chamado a cooperar com a criação de atividades ao ler nas elipses, marcas temporais e movimentos que são expressos na narrativa dos quadrinhos. O autor da HQ La Belle et la Bête (2014), conduz o desenvolvimento narrativo e temporal de forma que o leitor participe desta ação, ele observa o desenrolar dos fatos da perspectiva de Liam, e assim cria uma expectativa pela sequência dos fatos, como a passagem de tempo que ocorre nesta página. Esta passagem é marcada pela localização da lua, no início ela está atrás da casa de Liam, e ao fim da página se encontra acima do imóvel iluminando o barco voador que se aproxima.

Nesta página, há novamente uma transestilização (GENETTE, 2010, p. 271) de estilo e de gênero, visto que o conto de Leprince de Beaumont (2011) carrega em sua estrutura textual todos os elementos do maravilhoso, por exemplo, a expressão "Il avait une fois..."16 (LEPRINCE DE BEAUMONT, 2011, p. 9) ${ }^{17}$, que indica o afastamento temporal da narração. A HQ La Belle et la Bête $(2014,2015)$ questionará o lugar dessa história no fantástico, afirmando que tudo que se passa em suas páginas é real; aqui o leitor fará um pacto ficcional, aceitando assim as diretrizes narrativas para a leitura.

Para Roas (2014, p. 51-53), além do pacto ficcional, a "percepção do real no texto (intradiegética)" é elemento mais importante, uma vez que a verossimilhança de

\footnotetext{
${ }^{16}$ Uma sequência textual típica encontrada no primeiro parágrafo de um conto de fadas, ancorando a narrativa em um tempo não especificado, indicando ao leitor que os elementos narrativos não estarão alocados em uma lógica do mundo real. Todorov (2008) classifica os contos de fadas como Maravilhoso. ${ }^{17}$ Havia certa vez... (LEPRINCE de BEAUMONT, 2014 p. 17).
} 


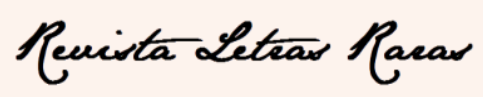

ISSN: 2317-2347 - v. 7, n. 2 (2018)

um texto fantástico é dupla. O leitor deve aceitar/acreditar no que o narrador conhece ou estabelece como algo impossível, e portanto, há uma fixação do narrador em uma realidade empírica dentro da narrativa. Assim, segundo Roas (2014, p. 52), o fantástico está dentro de uma realidade, e ao mesmo tempo "apresentando-se como um atentado contra essa mesma realidade que o circunscreve" (ROAS, 2014, p. 52),

O narrador da HQ propõe a seguinte afirmação (Fig. 1, quadrinho de abertura) “Tous les contes commencent par 'Il était une foi'...mais celui-ci n'est pas comme les autres...Il prend place aux temps des mythes et des légendes (...)"18. A frase serve como contraponto aos conceitos de Todorov (2008, p. 43-63) sobre o que é fantástico, estranho e maravilhoso, ${ }^{19}$ tornando escorregadia e ambígua a classificação deste gênero, não deixando elementos que faça o leitor acreditar que aquilo é real e ao mesmo tempo que não é: há um novo tipo de gênero apresentado nestas páginas que aglutina os anteriores.

Pode-se dizer que nesta passagem ocorre o que Roas (2014) explicita, o narrador aloca no real os fatos que irá narrar, direcionando o leitor a pactuar com esta realidade, mas ao mesmo tempo, na HQ La Belle et la Bête (2014, 2015), há o "atentado contra essa mesma realidade". Assim, ao verificar os apêndices na HQ (2014, 2015), percebese que o narrador tenta deslocar a história do campo do maravilhoso para o real, pois diz que a ação é verdadeira e que realmente ocorreu. Mas ao mesmo tempo há elementos contraditórios, como a presença de um barco voador e a veemente negação da mãe sobre a realidade dos fatos lidos por ela no livro de contos de fadas; além disso, no encadeamento narrativo da história, há presenças de um feiticeiro, de um monstro encantado, feitiços e maldições. Caberá à Belle questionar a verossimilhança dos fatos e acontecimentos quando, a partir de seu olhar, o que ela denomina real e não real começam a se interligar, por exemplo, um barco voar.

\footnotetext{
${ }^{18}$ Todos os contos começam por "era uma vez"... mas este aqui não é como os outros... Ele acontece nos tempos dos mitos e das lendas (tradução nossa).

${ }^{19}$ Segundo Todorov (2008), o estranho tem na narrativa uma explicação racional para eventos que possuem regras desconhecidas, que não são explicadas pela compreensão disponível das leis naturais e que necessitam de novas regras para defini-las. Por outro lado, ele denomina maravilhoso, o que tem como característica a criação de regras internas que não perturbam a verossimilhança narrativa, enquanto que, para o autor, no fantástico, as narrativas se estruturam a partir da representação da vacilação que o leitor sente ao se deparar com um fato sobrenatural, sem uma explicação lógica.
} 


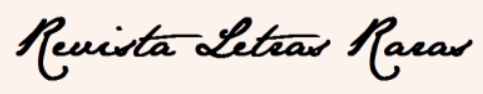

ISSN: 2317-2347 - v. 7, n. 2 (2018)

Apesar deste artifício, o verbal só provocou o deslocamento de um gênero, do maravilhoso para o maravilhoso científico, ou ficção cientifica como é denominado hoje. Aqui, houve uma transestilização de gênero (GENETTE, 2010, p. 271), uma reestruturação textual e imagética para se adequar ao gênero maravilhoso científico. Todorov (2008) indica o surgimento de uma subdivisão do maravilhoso que abarca essa diversidade de elementos. ${ }^{20}$

A ficção científica, tradução portuguesa para a termologia apresentada acima, possui uma organização análoga (TODOROV, 2008, p. 180) que acredita que o movimento narrativo obrigue o leitor a ver o quão próximo está dos elementos maravilhosos e o quanto eles estão presentes em sua vida. É o leitor que sofre o processo de adaptação, como concebe Todorov (2008, p. 181), e se coloca diante de um fato sobrenatural reconhecendo-o, ao final, com naturalidade. Sodré (1973, p. 8) ressalta que a narrativa de Ficção Cientifica é literária irrealista e apresenta a existência de um universo diferente, com certas anomalias plausíveis, mas que representa o senso comum, reproduzindo os ethos utópicos das narrativas místicas da Idade Média. Na Ficção Científica, segundo o autor, o ponto de vista narrativo é impessoal, mas o narrador é representado como testemunha. A narração funciona na terceira pessoa e relata os fatos, enquanto no maravilhoso, o narrador não é representado, a visão é impessoal e o narrador desaparece na narrativa.

No conto de Leprince de Beaumont (1756), não há uma interferência do narrador, ele também é impessoal, respeitando assim as diretrizes do maravilhoso "Il y avait une fois un marchand qui était extrêmement riche ${ }^{21}$ (LEPRINCE DE BEAUMONT, 2011, p. 9) enquanto que na HQ, o narrador se apresenta na primeira página, “Aux confins d'une contrée reculée, un enfant s'apprête à s'endormir sans se douter qu'une terrible menace se dirige vers son village..." [...] "Il prend place aux

\footnotetext{
20 O maravilhoso instrumental ou maravilhoso científico, hoje, denominado como science-fiction, tem como característica explicar um fato de maneira racional, mas a partir de leis que a ciência contemporânea não reconhece. (...) A Science-fiction atual, quando não desliza para a alegoria, obedece ao mesmo mecanismo, pois são narrativas que, a partir de premissas irracionais, os fatos se encadeiam de uma maneira perfeitamente lógica, possuindo uma intriga, diferente do conto fantástico. (TODOROV, 2008, p. 63, grifos do autor).

${ }^{21}$ Era uma vez um comerciante muito rico (...) (LEPRINCE DE BEAUMONT, 2016)
} 


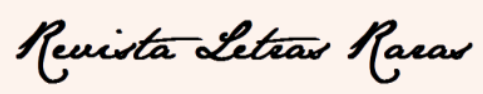

ISSN: 2317-2347 - v. 7, n. 2 (2018)

temps des mythes et des légendes (...)”'(L'HERMENIER, 2014, p. 3) 22. Há o indicativo de que Belle realmente seja a narradora desta história (isso será comprovado com o decorrer deste artigo), visto que uma das características de uma ficção científica é uma testemunha em terceira pessoa que relata os fatos, o que ocorre na HQ La Belle et la Bête $(2014,2015)$.

O narrador onisciente apresenta as premissas conceituais da narrativa, adiantando elementos que serão explorados no desenvolvimento da trama. A página de abertura da HQ (Fig. 1) se mostra de relevante importância, pois é o equivalente aos dois parágrafos introdutórios apresentados anteriormente. O principal indício de que o narrador onisciente seja Belle é uma frase emitida por ela no decorrer da narrativa, que aparecerá no prólogo do tombo 2: “L'amour est plus fort que tout...Il peut accomplir des miracles !" (L'HERMENIER, 2014, p. 39). O reaparecimento desta frase não é mais emitido por Belle, mas pelo narrador, assim indicando a possível relação entre narrador e Belle.

\section{Linguagem HQ e a construção de sentidos}

Belle é uma das personagens principais tanto no romance de Villeneuve (2011) quanto no conto de Leprince de Beaumont (2011) ao seu lado Bête. É a relação entre eles que permitirá que a história se desenvolva. Vale ressaltar, Leprince de Beaumont (2011) adaptou e alterou muitas das linhas narrativas que Villeneuve (2011) estabeleceu na história do romance, é a história do conto que se perpetuou e que serve como base para o filme da Disney The Beuty and the Beast (1994). Apesar da introdução de personagens novos, como Liam, Diane e o Mago, a HQ La Belle et la Bête (L'HERMENIER, 2014) orbita sobre as ações diretas ou indiretamente de Belle.

É por meio da trajetória narrativa de Belle que transcorrem as ações de desenvolvimentos, ela representa o elo entre todos os personagens de forma direta ou

\footnotetext{
22 Aconteceu nos tempos dos mitos e das legendas [...] Nos confins de uma terra distante, uma criança se prepara para dormir sem perceber que uma ameaça terrível se dirige para sua cidade... (...) Aconteceu no tempo dos mitos e das lendas(L'HERMENIER, 2014, p. 3, tradução nossa).
} 


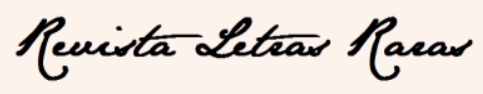

ISSN: 2317-2347 - v. 7, n. 2 (2018)

indireta, sendo a responsável pelo fim dos conflitos narrativos. Juntamente a Belle, outro personagem de grande importância é Bête, enfeitiçado, recolhe almas para alimentar o Mago. Assim, em L'Hermenier, (2014) manteve-se a mesma hierarquização dos personagens como é apresentada no conto e no romance.

Seus destinos vão se unir em uma dessas viagens atrás de almas: Belle para defender sua família, se oferece como prisioneira, e acaba em uma cela no barco de Bête. O personagem Liam aparece nessa relação a partir desse movimento, ele se infiltrará no navio voador para libertar Belle. Em L’Hermenier, (2014), há a introdução, como já dito, do triângulo amoroso entre Liam, Belle e Bête.

É de grande importância a relação entre Belle e Bête, tanto no conto e romance como na HQ, assim entender como ocorre o primeiro contato entre eles e verificar suas interações será de grande valia para compreender a narrativa. A análise a seguir contempla o primeiro encontro de Belle e Bête na HQ de L'Hermenier, (2014) e as progressivas alterações de sua relação (uma grande inimizade transformada em grandes aliados). O que construirá esta alteração é o fato de Belle encontrar, como dito antes, o livro de bordo de Bête e descobrir sua verdadeira história (como será melhor desenvolvido adiante).

O primeiro encontro dos dois personagens na HQ (Fig. 2) é marcado por reações faciais opostas: Belle, expressa raiva e descontentamento, Bête, frieza. Aqui há o retorno da calha negra, que é introduzida nas páginas inicias (Fig. 1). Ao analisar a HQ La Belle et la Bête $(2014,2015)$, pode-se observar que a cada mudança narrativa, ou que tenha uma importância ao desenvolvimento da história, as calhas são negras, servindo assim, para evidenciar o fato (por exemplo, a primeira vinda do barco voador de Bête ao vilarejo de Bêlle, que resulta na morte da mãe de Liam, a perda da fortuna do pai de Belle, ou quando o Mago aparece pela primeira vez).

Os dois quadros longitudinais (Fig. 2), lado a lado, indicam que as ações estão ocorrendo simultaneamente. O rosto de Bête, em seu quadro em plano plongé (GAGNIN, 2015, p. 115), está indicando a superioridade que ele tem perante a ação, enquanto que o rosto de Belle é focalizado a partir de seus olhar voltado para cima, em um plano em grande detalhe, evidenciando suas emoções. A predominância de tons 


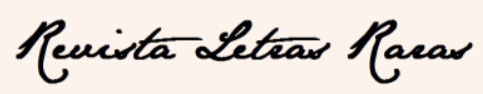

ISSN: 2317-2347 - v. 7, n. 2 (2018)

escuros e um nuance vermelho introduz a relação tensa e perigosa que eles terão ao longo da HQ La Belle et la Bête (2014, 2015).

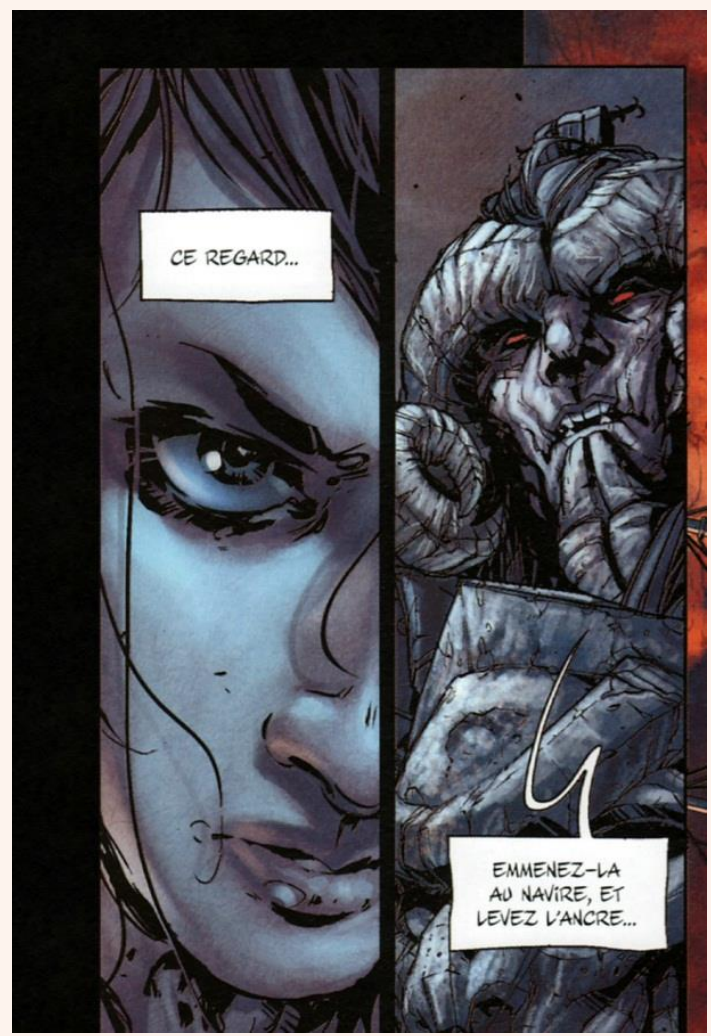

Fig. 2: L’Hermenier, 2014, p. 20

$\mathrm{Na} \mathrm{HQ}$, a relação não se inicia de forma cordial como ocorre no conto. Enquanto no conto Bête tenta ser o mais agradável e educado, mesmo que a presença dela ali seja fruto de uma ameaça, a sua prioridade é seu bem estar. Em seu primeiro encontro, questiona se a vinda dela até ali foi por livre escolha, ao receber uma reposta afirmativa, ele providencia uma boa hospedagem:

(...) Elle résolut de se promener en attendant et de visiter ce beau château.

Elle ne pouvait s'empêcher d'en admirer la beauté. Mais elle fut bien surprise de trouver une porte sur laquelle il y avait écrit : Appartement de la Belle. Elle ouvrit cette porte avec précipitation et fut éblouie de la magnificence qui y régnait. Mais ce qui frappa le plus sa vue fut une grande bibliothèque, un clavecin et plusieurs livres de musque. On ne veut pas que je m'ennuie, dit-elle tout bas. Elle pensa ensuite : Si je n'avais qu'un jour à demeurer ici, on ne m'aurait pas ainsi pourvue. Cette pensée ranima son courage. Elle ouvrit la bibliothèque et vit un livre où il y avait écrit en lettres d'or: Souhaitez commandez: vous êtes 


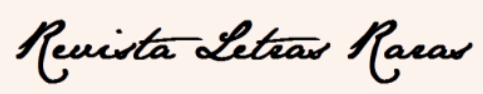

ISSN: 2317-2347 - v. 7, n. 2 (2018)

ici la reine et la maîtresse. (LEPRINCE DE BEAUMONT, 2011, p. 26-27, grifo do autor). ${ }^{23}$

O fato de Belle ter ido ao castelo por livre escolha é um elemento característico importante para quebrar a maldição. Este cuidado faz com que Belle reveja os seus conceitos preestabelecidos e passe a conviver de forma cordial com Bête. Enquanto na cena contida no tombo 1 da HQ La Belle et la Bête (2014), apesar de Belle oferecer-se no lugar das irmãs, o relacionamento dela com Bête é tenso inicialmente, visto que não há diálogo e ela é prisioneira sem direito a nenhum privilégio. Esta situação mudará no instante em que Belle encontrar um livro de bordo e conhecer a real história por trás da maldição, mudando sua atitude e se disponibilizando a ajudar Bête. A introdução do livro como peça importante na construção narrativa só será possível devido ao entrelaçamento de ações que mostram o gosto de Belle pela leitura.

Como no romance e no conto, na HQ Belle e Bête são os personagens principais, como dito acima, e suas histórias conduzem à trama narrativa. Estes personagens, nesta nova adaptação, fazem alusões às características contidas no conto de 1756 e no romance de 1740, pois há uma hipertextualização destas histórias. Além dessa repetição dos personagens principais, há outros elementos que são retomados nesta adaptação: a rosa, o prazer pela leitura de Belle, as irmãs, a escolha que a protagonista precisará fazer para manter seu pai e família vivos.

Contudo, pode-se notar uma nova estrutura narrativa apresentada na HQ (2014, 2015) construída em torno de uma rede de relações entre Belle, Liam, Bête, Mago e Diane, visto que as ações dos três últimos personagens influenciam a vida dos dois primeiros. Na passagem a seguir, Liam e Belle são apresentados adultos (Fig. 3).

\footnotetext{
23 Enquanto isso, decidiu passear e visitar o belo castelo. Não podia deixar de admirar a sua beleza e ficou muito surpresa ao encontrar uma porta com a inscrição: Aposento de Bela. Abriu a porta com pressa e ficou impressionada com a grandiosidade do quarto. O que mais a surpreendeu foi uma grande biblioteca, um cravo e vários livros de música. "Não quer que me entedie", disse, em voz baixa. E pensou: "Se eu fosse ficar apenas um dia aqui, não teria providenciado tanta coisa". Esse pensamento a animou novamente Abriu a biblioteca e viu um livro onde estava escrito em: Deseje, ordene, você é a rainha e dona deste lugar. (LEPRINCE de BEAUMONT, 2014 p. 38-39).
} 


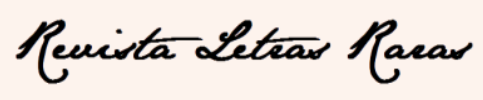

ISSN: 2317-2347 - v. 7, n. 2 (2018)

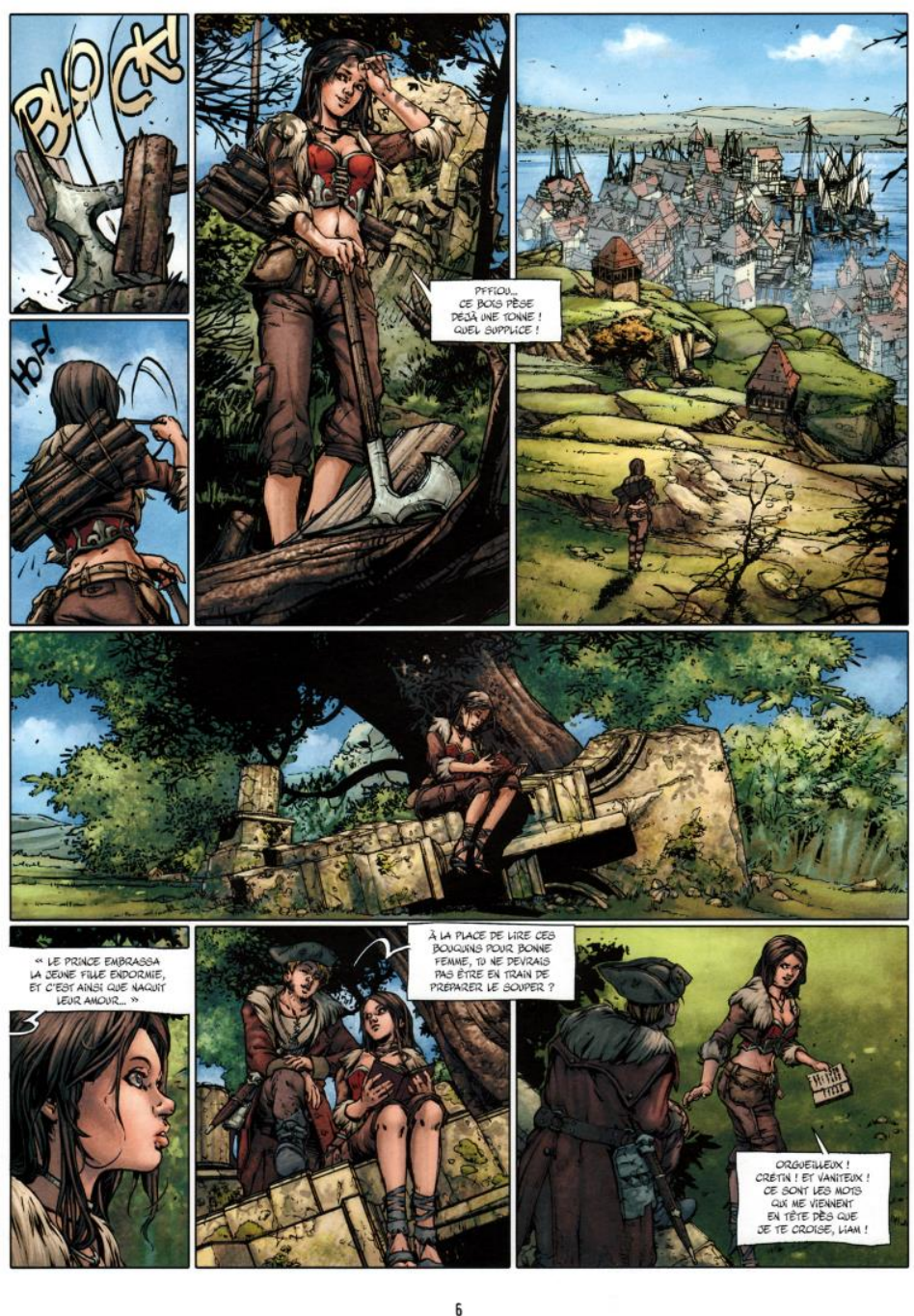

Fig. 3: L’Hermenier, 2014, p. 6

A cena se desenrola do primeiro quadrinho, panorâmico, em que é possível ver Belle, após terminar a tarefa de cortar lenha, sentada lendo um livro, embaixo de uma árvore. Sua leitura é interrompida por uma voz distante que é representada por um balão de fala que se apresenta aberto com um rabicho indicando sua origem fora do campo visual do quadrinho. O rosto de Belle é focalizado em um primeiro plano e sua expressão indica surpresa. O quadro seguinte dá continuidade à ação mostrando Liam atrás de Belle e a sequência do diálogo. A cena é interrompida por Belle, irritada, que ofende Liam e diz que o rapaz é "orgueilleux, crétin, vaniteux" (orgulhoso, cretino, 


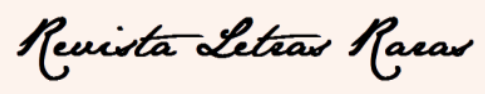

ISSN: 2317-2347 - v. 7, n. 2 (2018)

vaidoso). A narrativa é construída com diferentes interações modais: os quadrinhos em sequência, com tamanhos diferenciados, do primeiro que explicita a particularidade, ao último que enquadra os dois personagens para indicar o movimento da ação. Juntamente com os balões, o diálogo e as cores constroem a narrativa, pois, segundo Cagnin (2015, p. 179), a identificação imagética ou de figuras que configuram os quadrinhos é uma espécie de fio condutor da narrativa e tem a função primordial de contar a história, sempre tendo o auxílio do verbal e das cores.

Vale ressaltar, que nestes quadros há a primeira referência ao gosto de Belle por livros, que é sempre tão enfatizada em qualquer adaptação sobre esse tema. No conto de Beaumont (1756), a passagem abaixo representa a primeira vez que isso é citado e serve para diferenciar o gosto de Belle daquele do das suas irmãs:

Elles allaient tous les jours au bal, à la comédie, à la promenade, et se moquaient de leur cadette, qui employait la plus grande partie de son temps à lire de bons livres. (LEPRINCE DE BEAUMONT, 2011, p. $12-13){ }^{24}$

O hábito de leitura neste caso é qualificativo, como este conto tinha a função de educar as jovens de sua época, servia para ressaltar a boa educação que uma dama deveria ter. Uma forma de distração depois de concluir os seus afazeres domésticos: "Quand elle avait fait son ouvrage, elle lisait, jouait du clavecin, ou bien chantait en filant." (LEPRINCE DE BEAUMONT, 2011, p. 12-13) ${ }^{25}$

Esta sequência apresenta pela primeira vez os personagens após o ataque do navio e, em um primeiro momento, não se sabe ao certo quem são, mas ao longo da HQ (2014, 2015) é revelado que aquele menino é Liam, um amigo de infância de Belle. Essa é uma nova estrutura narrativa apresentada na HQ La Belle et la Bête (2014) que terá como função apresentar a relação entre os dois personagens e construir as novas relações entre Belle, Liam, Bête, Mago e Diane. A sequência introduz um eixo narrativo que terá continuidade com Liam buscando vingar a morte materna ao mesmo tempo em

24 (...) Iam todos os dias ao baile, ao teatro, ao passeio e zombavam da irmã caçula, que passava a maior parte do tempo lendo bons livros. (LEPRINCE DE BEAUMONT, 2014 p. 18).

25 (...) Quando o ofício estava terminado, ela lia, tocava cravo ou cantava enquanto bordava. (...).(LEPRINCE DE BEAUMONT, 2014 p. 20). 


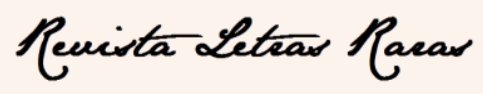

ISSN: 2317-2347 - v. 7, n. 2 (2018)

que tentará salvar Belle, aprisionada por Bête. Liam representa a introdução de um terceiro vértice à história, que gerará dois triângulos amorosos indiretos: Liam, Belle e Bête de um lado, e Belle, Diane e Bête, do outro, contudo, essas relações serão alteradas conforme a manipulação do Mago.

O triângulo amoroso é um elemento narrativo atual e popular, há uma expectativa do leitor para que esta situação ocorra em determinado momento da história. É elemento recorrente nas histórias atuais e representa um artifício inserido nessa HQ La Belle et la Bête (2014). É possível arriscar que esse elemento não poderia ser introduzido nas outras versões, visto o restrito código de conduta ao qual uma mulher deveria se submeter, e que não permitiria que ela se envolvesse afetivamente com dois homens ao mesmo tempo; esta é uma das características de uma graphic novel, a complexidade psicológica e narrativa.

Retomando a análise da cena (Fig. 3), pode-se constatar que Liam interrompe a leitura de Belle para zombar dos típicos livros direcionados às garotas que se envolvem com príncipes encantados e finais felizes (essa ideia retoma o objetivo da narrativa do conto). É um índice que remete às ações narrativas futuras, Liam é apaixonado por Belle e sentirá ciúmes da sua relação com Bête e, por este motivo, se juntará ao Mago em busca da realização de uma dupla vingança: a morte de sua mãe e a suposta paixão de Belle por Bête.

A personagem se mostra ao longo da HQ (como no romance e no conto) uma voraz leitora e afirma que os livros são seus companheiros ${ }^{26}$. É por meio de sua curiosidade e gosto pela leitura que se inicia a interação com Bête. Após ser presa e ser mantida em uma cela por alguns dias, Bête visita Belle e não lhe dirige nenhuma palavra. Irritada com a situação, a protagonista começa a vasculhar o local, e percebe que se trata de uma cabine, um local que contém uma estátua de um belo guerreiro e um livro de bordo. Inicia a leitura e descobre um pouco mais sobre as aventuras do capitão de um navio que vive altas aventuras, apaixona-se e casa. Finalmente, ela conclui que este guerreiro é a fera que a aprisionou. Prisioneira, Belle questiona a qualidade da comida e suas condições de cárcere, o que leva Bête a alimentá-la de forma adequada,

\footnotetext{
${ }^{26}$ «Les livres sont les meilleurs compagnons, ils ne vous quittent pas et vous racontent les plus belles histoires... » (L’Hemenier, 2015, p. 6)
} 


\section{Revista Leteas Pacas}

ISSN: 2317-2347 - v. 7, n. 2 (2018)

levando-a até o salão principal. Durante a refeição, uma nova relação começa a se formar e eles começam a se entender. A cena a seguir (Fig. 4), representa Belle buscando livros na biblioteca do navio e Bête tentando reaver seu livro de bordo ainda em poder de Belle.

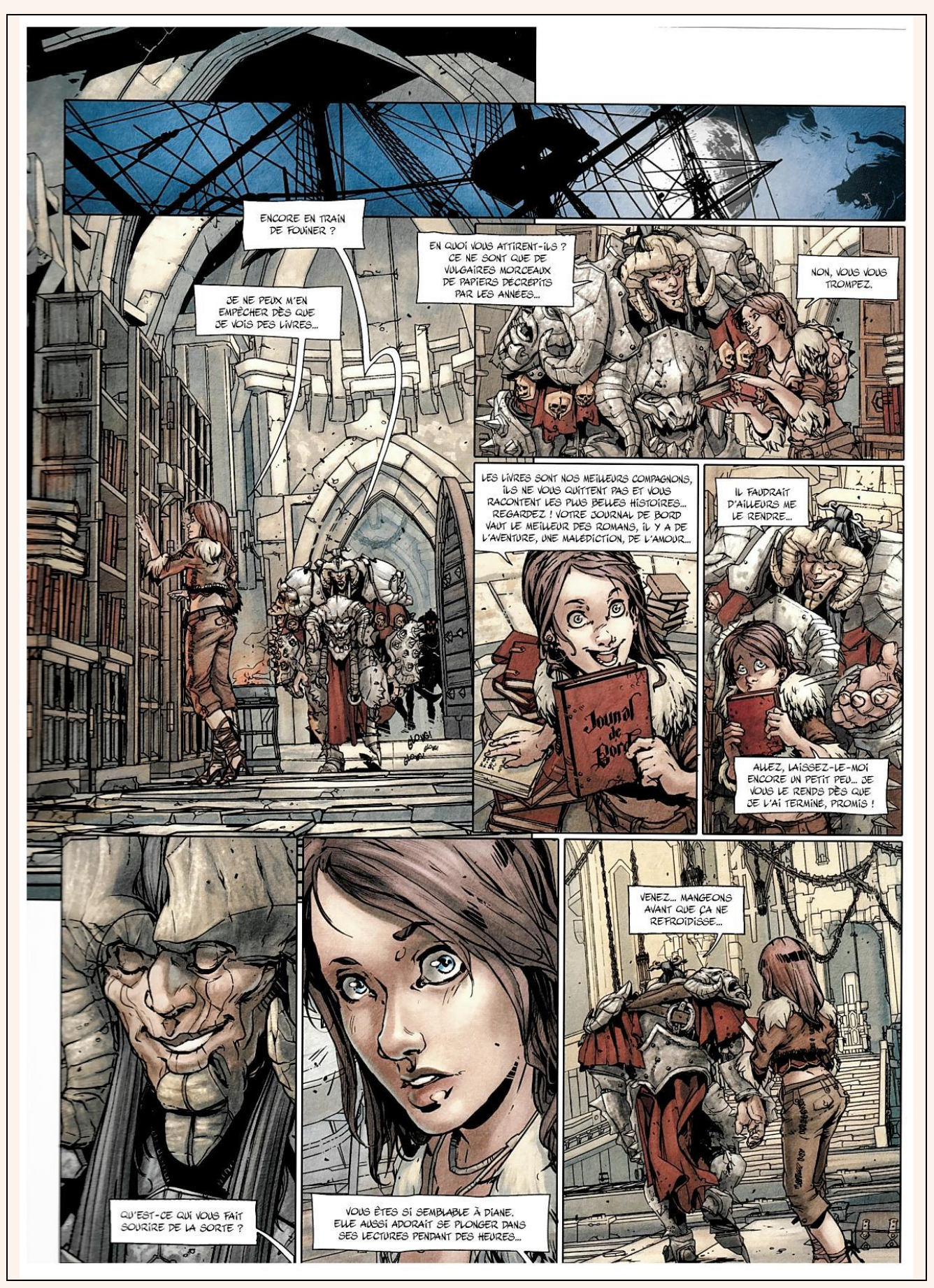




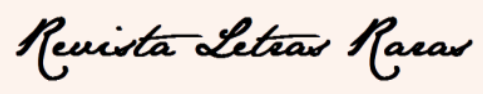

ISSN: 2317-2347 - v. 7, n. 2 (2018)

Fig. 4: L’Hermenier, 2015, p. 6

A construção narrativa desta cena se dá por meio da interação de diversos modais: imagens, cores, gestos, expressões visuais e diálogos. O primeiro quadrinho horizontal localizado na parte superior da cena indica o espaço e o tempo: o navio voador, durante a noite. O quadrinho maior à esquerda, apresenta um plano panorâmico em perspectiva que tem a função de localizar a cena na biblioteca, este tipo de plano tem a função de englobar não só os personagens, como afirma Gagnin (2015, p. 109), mas serve também para demonstrar grandiosidade. Os outros três quadrinhos estão em plano americano (mostram os personagens até o joelho). A cena é ligada de forma contínua com a invasão do balão do primeiro plano americano, no qual Bête pergunta a Belle como velhos pedaços de papéis podem atraí-la.

Esta cena exemplifica a forma como, ao se correlacionar, elementos multimodais constroem a narrativa. As expressões dos dois personagens dão o tom enunciativo, enquanto a primeira cena de interações deles há tensão em seus rostos (Fig. 2), aqui claramente eles estão se divertindo, estão alegres e suas falas passam por empolgação e brincadeira. Bête tenta reaver seu livro de bordo, ele não cita em sua fala que o livro que deseja é o livro de bordo, mas a imagem do livro escrito nele "journal de bord" completa o sentindo do diálogo. Na mesma cena, Belle pede que deixe que termine de lê-lo, a expressão dela é totalmente infantil, com olhos grandes, radiantes (essa imagem remete à de uma criança feliz). O quadrinho seguinte mostra Bête com uma expressão divertida ao pedir seu livro de volta e Belle com uma expressão visual bem diferente, agora assustada com a possibilidade de não poder terminar a leitura do diário. É importante ressaltar essa transfiguração de Belle, apenas nesses dois quadrinhos ela aparece com traços infantis.

Já na cena que se passa nos dois quadrinhos seguintes, Bête sorri e Belle (agora com traços de mulher) pergunta o motivo daquele sorriso, e a fera diz que Belle lembra Diane sua esposa, porque "ela também adorava mergulhar em suas leituras por horas..." ${ }^{27}$ (L’Hermenier, 2015, p. 6, tradução nossa). Estes quadrinhos são construídos em primeiro plano (CAGNI, 2015, p.. 107), mostrando a cabeça e as expressões faciais

\footnotetext{
${ }^{27}$ « Vous êtes si semblable à Diane. Elle aussi adorait se plonger dans ses lectures pendant des heures... » (L’Hermenier, 2015, p. 6).
} 


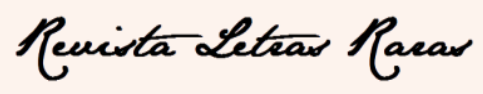

ISSN: 2317-2347 - v. 7, n. 2 (2018)

com o objetivo de ressaltar a emoção dos personagens. Em seguida vemos um plano americano (CAGNI, 2015, p.. 108), em que mostra os dois personagens, Bête de costas indo em direção à porta e chamando Belle para jantar, e Belle também de costas, ainda segurando o livro. Não há nenhum diálogo que afirme que Bête deixou Belle ficar com o livro de bordo, mas o fato de a imagem evidenciar que ela ainda o segura, informa ao leitor que ela teve permissão para continuar sua leitura.

Entre a cena do primeiro encontro (Fig. 2), na qual as cores predominantes eram escuras mostrando a tensão dos rostos dos dois (analisada anteriormente) e esta cena na biblioteca (Fig. 4) em que as cores são predominantemente claras, pode-se notar um contraponto à relação dos personagens. O vermelho, nesta cena, assume uma nova função: se na Fig. 2 ele introduz a relação tensa e perigosa entre os personagens (vermelho vivo), nessa sequência, ele faz um paralelo entre o manto de Bête e seu livro de bordo (também vermelho). O vermelho nessa passagem assume tons de terra e se harmoniza ao restante das cores (tons de bege, ocre, marrom).

Antes desta cena, como dito anteriormente, os dois tiveram um jantar em que discutiram o motivo de Belle não ter medo de Bête, seu propósito ao se oferecer no lugar de sua família, seu esforço por entender como o barco pode voar; ao fim da conversa, Belle pode perambular pelo navio com a condição de não tentar escapar. Nesta adaptação, a cena da biblioteca é um ponto chave da transformação do relacionamento dos dois, pois a partir daqui, Belle não é mais uma prisioneira, ela se transforma em sua aliada na busca de Bête para salvar sua amada esposa. Há uma empatia crescente em relação à Bête, pois Belle perceberá que ele não é um monstro, sua aparência decorre da proteção que dispensa à Diane.

A relação de Belle e Bête, do seu primeiro encontro (com cores predominantes escuras, expressões faciais tensas e cheias de ódio), para a cena da biblioteca (cores claras, diversos diálogos e expressões felizes e alegres) pode ser evidenciada por vários artifícios. Muitos dos elementos contidos nestas mudanças encontram-se nas imagens, e não nos diálogos, é a interação destes dois modais que geram a criação de sentido da cena. As duas cenas fazem um paralelo à narrativa do conto e do romance que constroem uma evolução da relação inicial de conflito dos personagens à relação de afeto. 


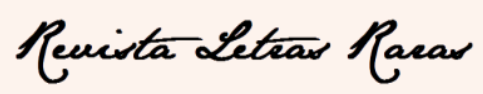

ISSN: 2317-2347 - v. 7, n. 2 (2018)

Os dois protagonistas surgem como aliados na busca da salvação de Diane e Liam; será o amor de Belle por Liam, e não por Bête, que os salvará. Assim, haverá uma quebra de expectativa, os protagonistas não ficarão juntos, como normalmente se almeja em triângulos amorosos. Mesmo que tudo leve a crer que no fim da história Liam morreu, o jovem rapaz, meio besta, meio homem, sobrevive à batalha contra o Mago e aparece no prólogo da HQ em estudo, observando uma rosa, a flor que lembra sua amada Belle.

\section{Considerações Finais}

Os impactos narrativos em uma transposição monomodal para uma multimodal dependem não apenas da intenção, mas também da função que o autor quer dar à narrativa, podendo ampliar, reduzir ou acrescentar elementos. O estilo definirá a escolha das imagens em HQ, como ocorreu no corpus deste artigo.

Na HQ La Belle et la Bête (2014, 2015), o autor optou por definir um gênero específico para conduzir a sua narrativa, a Ficção Científica. Este gênero tem suas próprias características e regras que proporcionam uma forma particular de construção, como dito anteriormente. Nesta HQ La Belle et la Bête (2014), optando por um barco voador como elemento mágico, uma invenção humana que pelo senso comum não poderia voar, o autor evidenciou sua proposta narrativa, deslocando a narrativa da realidade do leitor e colocando-a em um mundo de fantasia.

O narrador tenta evidenciar que sua história é real, apesar de em um primeiro momento parecer onisciente e não identificável. Há indícios de que Belle seja esse narrador, como dito, mostrando os fatos ocorridos em sua perspectiva, reais; toda a estrutura imagética foi adequada para comportar as características deste gênero. Por isso, é aceitável que Bête passe de um príncipe encantado que sofreu uma maldição de uma fada cujo motivo não é explicitado no conto (1756), para um pirata que se apaixonou por uma princesa e, devido a esse amor, é enfeitiçado. Belle corresponde às características esperadas de uma garota contemporânea, esperta, corajosa, astuta, que 


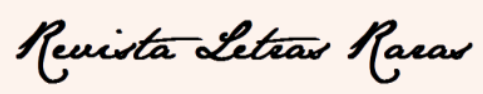

ISSN: 2317-2347 - v. 7, n. 2 (2018)

luta por seus ideais e por seu amor, sem se prender a padrões, indo em direção oposta a sua representação no romance (1740) e no conto (1756).

Este estudo teve como propósito analisar as formas pelas quais a narrativa da conhecida história La Belle et la Bête foi adaptada e atualizada, criando assim uma obra original que mesmo retomando elementos do romance (1740) e do conto (1756) em uma HQ (2014), tem uma nova estrutura narrativa tornando-se única. Tendo em vista a evolução da sociedade para uma linguagem cada vez mais visual, na qual há combinações entre palavra (oral e escrita) e visual (imagem), que se configuram em textos multimodais, o presente artigo pretende contribuir para a construção de um letramento nesta área que se encontra em constante ampliação de seus estudos.

\section{REFERÊNCIAS}

DIONISIO, A. P. “Gêneros Textuais e Multimodalidade.” In: KARWOSKI, A. M;

GAYDECZKA, B.; BRITO, K. S. (Org.). Gêneros textuais: reflexões e ensino. São Paulo: Parábola Editorial, 2011.

DURRENMATH, M L. L"adaptation d'un conte de fées littéraire au cinéma: l'exemple de La Belle et la Bête de Walt Disney. Université de Lyon, Setembro, 2001.

DONIS, A.D. Sintaxe da linguagem visual. São Paulo: Martins Fontes, 2003.

FRASER, T. O guia completo da cor. São Paulo: Editora Senac São Paulo, 2007.

GAGNIN, A.L. Os quadrinhos: Linguagem e Semiótica. São Paulo: Criativo, 2015.

GENETTE, G. Palimpsestes. La littérature au second degré. Paris: Editions du Seuil, 1982.

GROENSTEEN, T. Système de la bande dessinée. Paris, Presses Universitaires de France, 2011.

HEMAIS, B. Multimodalidade: enfoque para o professor de ensino médio Rio de Janeiro: Janela de Ideias, 2010.

LEBRUN, Monique (coordenação), LACELLE, Nathalie \& BOUTIN, Jean-François. La littératie médiatique multimodale: de nouvelles approches en lecture. Québec: Presses de l'Université du Québec, 2012.

LEPRINCE DE BEAUMONT, J.-M. La Belle et la Bête et autres contes. Italie: Éditions Larousse, 2011.

A Bela e a Fera. 1.ed. Tradução Marie - Hélène Catherine Torres; Ilustrações de Laurent Cardon São Paulo: Poetisa, 2014. 


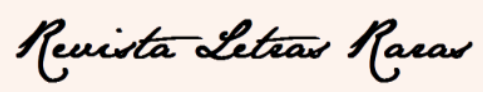

ISSN: 2317-2347 - v. 7, n. 2 (2018)

L'HERMENIER, LOOKY, DEM. La Belle et la Bête, volume 1/2. France: Bamboo Édition, 2014.

L'HERMENIER, LOOKY, DEM. La Belle et la Bête, volume 2/2. France: Bamboo Édition, 2015.

MCCLOUD, S. Desenhando Quadrinhos. São Paulo: M Books do Brasil Editora, 2008.

NASCIMENTO, R. G.; BEZERRA, F. A. S.; HEBERLE, V. M.. "Multiletramentos: iniciação à análise de imagens". Linguagem \& Ensino, v. 14, n. 2, p. 529-552, 2012.

PLAZA, J. Trandução Intersermiótica. São Paulo: Perspectiva, 2003.

RODRIGUES, V. S. Histórias em quadrinhos X Ensino de Literatura: por um projeto de formação de leitores menos "quadrados". (2013). Folhas. Grau (Dissertação) (Mestrado em Letras)- Faculdade de Letras - Universidade Federal do Rio Grande do Sul, 2013.

SODRÉ, M. A Ficção do tempo. Petrópolis: Editora Vozes Ltda, 1973.

TODOROV, T. Introdução à Literatura Fantástica. São Paulo: Editora Moraes, 2014.

VIEIRA, E. V. C. Das apropriações literárias: algumas considerações a respeitos da literatura e do suplemento de Derrida. Minas Gerais: Em Tese, V. 16, nº 13, 2010.

VILLENEUVE, G-S. de. La Belle et la Bête. Paris: Éditions Gallimard, 2010. “A Bela e a Fera In: A Bela e a Fera. Rio de Janeiro: Zahar: 2016, p. 59-233.

Recebimento: 07/07/2018

Aceite: $26 / 09 / 2018$ 